\title{
PERGESERAN DESAIN BANGUNAN DALAM MASA PERKEMBANGAN ARSITEKTUR DI INDONESIA
}

\author{
Qurratul Aini \\ Program Studi Arsitektur, Fakultas Teknik Universitas Muhammadiyah Aceh, email: \\ qurratul.aini@unmuha.ac.id
}

\begin{abstract}
ABSTRAK
Arsitektur Indonesia mengalami perkembangan dari masa ke masa. Perkembangannya terlihat dalam bentuk fasad dan respon terhadap lingkungan, di mana mengalami pergeseran desain dari masa tradisional hingga masa modern. Penelitian ini bertujuan untuk menganalisis pergeseran desain secara fisik, yang terjadi dalam periode perkembangan arsitektur Indonesia, dengan metode kualitatif deskriptif. Dalam perkembangannya terdapat beberapa pergeseran desain bangunan yang terlihat pada pergeseran penggunaan material, pergeseran prinsip penerapan material, perubahan desain elemen pembentuk ruang, yaitu lantai dan atap. Style bangunan juga mengalami pergeseran dari style tradisional, style modern hingga style yang kembali mempertimbangkan pengaruh lingkungan dalam desainnya.
\end{abstract}

Kata kunci: Arsitektur, Pergeseran Desain, Perkembangan Arsitektur Indonesia

Info Artikel:

Dikirim: 7 Juli 2021; Revisi: 26 Juli 2021; Diterima: 9 Agustus 2021; Diterbitkan: 30 September 2021

(C2021 The Author(s). Published by Arsitekno, Architecture Program, Universitas Malikussaleh, Aceh, Indonesia under the Creative Commons Attribution 4.0 International License (https://creativecommons.org/licenses/by/4.0/).

\section{PENDAHULUAN}

Perkembangan arsitektur dari waktu ke waktu terus mengalami perubahan, di mana dapat terjadi seiring dengan perubahan kebiasaan manusia dan perkembangan teknologi yang ada di suatu daerah. Pernyataan Moore [1] dalam bukunya menguraikan arsitektur berkembang dalam tiga (3) masa, yaitu; pertama Masa Sebelum Industrialisasi (pre-industrial architecture), di mana pada masa ini berkembang pada tahun $1800 \mathrm{M}$, di mana arsitektur ditandai dengan sumber daya alam yang berlimpah dan teknologi yang terbatas. Selubung bangunan berfungsi sebagai pengontrol utama antara kondisi lingkungan dalam dan luar. Eksisting tapak merupakan kebutuhan yang tidak dapat diabaikan.

Kedua, Arsitektur Pada Masa Industrial (industrial architecture), di mana pada masa ini berkembang pada saat revolusi industri. Arsitektur tidak sepenuhnya ditekankan pada bentuk, namun diarahkan secara drastis ke pengaruh struktur, ekonomi dan keberadaan material baru seperti baja. Pada masa industrial architecture berkembang beberapa pergerakan, yaitu; pergerakan modern, berkembang pada abad XX (pasca perang dunia I), di mana gaya arsitektur tercermin pada penggunaan ornamen yang berlebihan dengan memberi kebebasan dalam mengeksplorasi bentuk bangunan. Beberapa arsitek membatasi pertimbangan terhadap kondisi tapak, penghawaan alami dan pencahayaan, namun lebih menekankan proses desain dengan menggunakan teknologi baru. Selanjutnya pergerakan respon terhadap iklim, yaitu pergerakan yang merespon pengaruh kasus peningkatan penggunaan energi pada pergerakan modern. Arsitektur yang menampilkan solusi energi secara intensif, di mana teknologi bangunan didesain secara holistik dan terintegrasi antara bangunan dan lingkungan.

Ketiga, Setelah Masa Industrial (post-industrial architecture). Pada masa ini para arsitek sudah mulai memikirkan ketersediaan energi yang semakin terbatas serta melibatkan lingkungan dalam pembangunan, sehingga akan berpengaruh pada biaya konsumsi energi yang digunakan. Di masa ini, banyak orang sudah kembali memikirkan pembelajaran terdahulu dari nilai arsitektur tradisional dalam penekanan desain bangunan. 
Berdasarkan tiga (3) masa perkembangan arsitektur tersebut, desain arsitektur khususnya di Indonesia tentunya memiliki perubahan dan perkembangan desain bangunannya. Perubahan yang terjadi secara langsung terlihat dari fasad bangunannya. Tulisan ini bertujuan untuk mendeskripsikan pergeseran desain bangunan secara umum yang ditinjau dari masa perkembangan arsitekturnya. Uraiannya disesuaikan berdasarkan hasil penelitian terdahulu, pendapat para ahli dan kondisi terkini.

\section{METODE PENELITIAN}

Metode yang digunakan adalah metode kualitatif deskriptif. Penelitian ini menjelaskan corakcorak arsitektur berdasarkan masa perkembangannya khusus di Indonesia. Penjelasannya dilakukan dengan menganalisis beberapa tulisan yang dirujuk dari beberapa buku-buku dan jurnal-jurnal terkait. Objek penelitian adalah desain arsitektur di Indonesia. Adapun variabel yang dilihat dalam penelitian ini adalah pergeseran desain dan elemen pembentuk ruang (lantai, dinding dan atap). Hasil yang diperoleh adalah berupa deskripsi yang menyimpulkan pergeseran desain yang terjadi dari masa ke masa pada desain arsitektur Indonesia.

\section{HASIL DAN PEMBAHASAN}

\subsection{Perkembangan Arsitektur di Indonesia}

Untuk menampilkan jati diri arsitektur di Indonesia Mangunwijaya, Prijotomo dan Pangarsa, menyatakan bahwa nilai lokalitas merupakan bagian penting yang harus dijaga [2]. Penekanan penting yang harus dipenuhi dalam menampilkan ciri arsitektur Indonesia yaitu menekankan pada pertimbangan dalam merespon kondisi lingkungan dan menekankan pada potensi setempat (lokalitas) yang memberikan ciri khusus dalam identitas arsitekturnya. Karakteristik arsitektur Indonesia tidak lepas dari pertimbangan kebiasaan dan keunikan alam.

Ragam arsitektur yang berkembang di Indonesia, yakni; (1) Arsitektur Tradisional, merupakan maha karya vernakular yang diakui secara aklamasi dan turun temurun dalam rentang waktu yang lama dan bahkan sangat lama [3]. Arsitektur tradisional berkembang dalam proses dan waktu yang panjang dan merupakan gambaran bentuk dan adaptasi terhadap lingkungan. Rumah tradisional terbentuk melalui representasi keinginan dan kebutuhan penghuni. Bangunan tradisional merupakan desain dengan kinerja kontrol iklim dan sistem struktur yang baik [4]. Kondisi tersebut berpengaruh pada penggunaan material, sistem struktur dan konstruksi pada rumah tradisional. Menurut Lefaivre dan Tzonis [5], arsitektur tradisional merupakan arsitektur asli daerah dengan struktur kayu yang kaku, yang dilengkapi dengan atap yang besar, overhangs yang luas dan dinding berpori (minimum wall) untuk memaksimalkan ventilasi. Jadi arsitektur tradisional adalah sebuah karya arsitektur yang mencerminkan adaptasi masyarakat terhadap lingkungan dalam rentang waktu yang lama, sehingga menjadi sebuah identitas bagi sebuah komunitas masyarakat tertentu.

(2) Arsitektur Vernakular, menurut Hendrik dan Rogi [6] bahwa desain arsitektur vernakular merupakan suatu penyesuaian model dengan variasi individual yang lebih beragam dari bangunan-bangunan primitif yang cenderung bersifat "open-ended", di mana kemungkinan variasinya sesuai dengan keinginan individual/masyarakat. Rapoport juga membedakan jenis bangunan vernakular yang berkembang, yaitu "pre-industrial vernacular" dan "modern vernacular". Bahkan Hendrik dan Rogi [6] mengungkapkan bahwa, terkait lingkungan dan keterbatasan sumber daya, bangunan-bangunan vernakular biasanya dibangun oleh pemiliknya sendiri atau komunitas setempat secara gotong royong dengan memanfaatkan beragam teknologi tradisional. Dalam hal ini, dapat dikatakan bahwa, arsitektur tradisional yang berkembang di suatu daerah merupakan bagian dari arsitektur vernakular, karena terbentuk dari adaptasi lingkungan dengan menggunakan material setempat. Hal tersebut juga diuraikan Mentayani dan Muthia [7], bahwa arsitektur vernakular adalah desain arsitektur yang mempertimbangkan iklim lokal, dengan menerapkan teknik pembangunan tradisional dan material lokal, dipengaruhi oleh unsur sosial, budaya, dan ekonomi masyarakat. Arsitektur vernakular merupakan istilah untuk mengkategorikan metode kontruksi yang menggunakan sumber daya lokal guna memenuhi kebutuhan lokal. Arsitektur vernakular berkembang untuk menterjemahkan lingkungan, budaya, dan sejarah dari daerah di mana karya arsitektur tersebut tercipta dan berada/eksis [3]. Jadi disimpulkan bahwa arsitektur vernakular adalah desain lingkungan binaan yang memiliki nilai 
lokalitas dan menggambarkan kondisi alam dan lingkungan setempat yang dapat bekembang setiap waktu dan bervariasi sesuai dengan keinginan pemiliknya.

(3) Arsitektur Modern Indonesia, dalam [8] dijelaskan bahwa, akhir abad ke-19 merupakan tahun-tahun perubahan, di mana dalam dunia arsitektur terwujud pencarian gaya baru arsitektur yang mencerminkan karakteristik budaya kawasan. Dalam kondisi ini, muncul perkembangan pemikiran dan pendekatan baru, yang berpengaruh pada keberagaman dunia arsitektur. Gaya arsitektur modern di Indonesia muncul dalam dua aliran, yaitu; (a) Arsitektur Kolonial, di mana gaya arsitektur ini dipengaruhi masa penjajahan Belanda, yang menjajah Indonesia selama 3,5 abad. Tampilan arsitektur kolonial Belanda di Indonesia berkembang sesudah tahun 1900 SM, yang merupakan bentuk penyesuaian dari arsitektur modern yang berkembang di Belanda dengan kondisi iklim tropis yang ada di Indonesia. Arsitektur ini berkembang sampai abad ke-19 yang juga dikenal dengan gaya Neo-Klasik. Gaya arsitektur ini mendominasi corak arsitektur di Indonesia sampai pada awal kemerdekaan. (b) Arsitektur Awal Kemerdekaan, merupakan arsitektur modern di Indonesia bermula pada dasawarsa terakhir masa penjajahan, ketika diperkenalkan kaidah rasionalis yang penting dalam perkembangan arsitektur. Di awal kemerdekaan, gaya arsitektur Indonesia selain mengandung nilai arsitektur Eropa, juga melirik arsitektur Amerika guna keluar dari pengaruh arsitektur Kolonial. Pada era ini terjadi Nasionalisasi dari gaya arsitektur, meliputi; Modernisme tahun 60-an, dimulai pada tahun 1957, di mana pada era ini muncul gedung-gedung pencakar langit, Nasionalisme dan Kontekstualisme, di mana muncul gedung-gedung bergaya barat berciri Indonesia, serta Internationalism, yang merupakan arah baru, di mana pendekatannya ditandai dengan kriteria teknologi yang tercermin pada teknik konstruksi dan material yang digunakan.

(4) Arsitektur Internasionalisme dan Rgionalisme. Berkembangnya arsitektur dengan gaya internasionalisme, menunjukkan estetika asing dan tanpa jati diri mulai menguasai wajah arsitektur indonesia. Kondisi tersebut menjadi awal mula munculnya gerakan regionalisme, yaitu gerakan yang bertujuan untuk memunculkan kembali nilai kedaerahan dalam setiap karya arsitektur dan menemukan jati diri arsitektur Indonesia. Perkembangan arsitektur di Indonesia muncul dalam berbagai konteks, yaitu; (a) arsitektur perniagaan yang menonjolkan kegiatan perekonomian, (b) permukiman penduduk yang dibedakan dalam tiga kelas, yaitu perumahan kelas atas (mencolok dan individualistis), kelas menengah (seragam) dan kelas bawah (semrawut, tidak lazim dan kumuh) dan (c) bangunan berlantai banyak (skyscraper) yang memakan banyak energi.

(5) Arsitektur Tropis, di mana terdapat tiga pertimbangan utama yang mempengaruhi desain arsitektur pada daerah tropis, yaitu manusia dan kebutuhannya, iklim dan ketidaknyamanannya serta material dan fungsi bangunannya [5]. Sejarah perkembangan arsitektur tropis secara umum, yaitu: arsitektur tradisional, merupakan arsitektur asli daerah dengan struktur kayu yang kaku, yang dilengkapi dengan atap yang besar, overhangs yang luas dan dinding berpori (minimum wall) untuk memaksimalkan ventilasi, arsitektur kolonial (1819-1950an) dengan menggunakan metode konstruksi Eropa dengan menggabungkan style Eropa dan style lokal kedaerahan serta disesuaikan dengan kinerja iklim dari bentuk tradisional, arsitektur kontemporer Eropa (1937), di mana perkembangan arsitektur kaca dengan penyesuaian iklim tropis dan metode konstruksi yang telah memikirkan konservasi energi, melalui pendekatan desain pasif dan aktif dan arsitektur modern tropical (1959), berkembang menggantikan arsitektur tropis kolonial selama periode postcolonial [5].

Di dalam [9] dinyatakan bahwa banyak perkembangan arsitektur yang terjadi di daerah tropis, yang hanya merealisasikan pengaruh Eropa modern, tanpa mempertimbangkan iklim dan kondisi daerah setempat. Karena fenomena tersebut, muncullah istilah arsitektur tropis yang merupakan karya arsitektur yang mencoba memecahkan problematik lingkungan yang berada di iklim tropis.

\subsection{Desain Bangunan yang Berkembang di Indonesia dalam Masa Perkembangan Arsitektur}

Bentuk keunikan alam yang mempengaruhi bangunan arsitektur salah satunya adalah iklim dan ilmu pengetahuan, di mana menpengaruhi arsitektur dari segi bentuk, material dan sistem konstruksian. Adapun corak atau desain bangunan yang muncul dalam masa perkembangan arsitektur Indonesia adalah: 
a. Arsitektur Tradisional

Rumah panggung merupakan salah satu ciri arsitektur yang umum ditemukan pada rumah tradisional yang ada di Indonesia, baik itu pada dataran tinggi maupun kawasan pesisir [10]. Ciri fisik bangunan tradisional Indonesia menurut Wondoamiseno adalah hampir semua bahan utamanya memakai material dari kayu, atap sebagai mahkota bangunan ditampilkan secara spesifik dan dapat berfungsi menangkis kondisi alam setempat, secara struktural tiang-tiang dan pasak-pasak saling berhubungan, dinding berfungsi sebagai penyekat dan bersifat transparan dengan sistem knock down, dan pada umumnya menggunakan sistem knock down, sehingga dapat dipindah-pindahkan [11].

b. Arsitektur Vernakular

Arsitektur Vernakular adalah arsitektur yang hadir dari proses yang panjang dan berulangulang sesuai dengan perilaku, kebiasan dan adat pada suatu tempat. Berkembang dari arsitektur rakyat, lahir dari masyarakat, tumbuh di masyarakat dan berpangkal pada tradisi etnik, yang dikenal dengan arsitektur tanpa arsitek [12]. Adapun ciri-ciri Arsitektur Vernakular antara lain; diciptakan masyarakat tanpa bantuan tenaga ahli (arsitek), mampu menyesuaikan dengan kondisi fisik, sosial, budaya dan lingkungan, dibangun dengan sumber daya yang ada, memiliki tipologi bangunan tradisional yang berkembang dalam wujud hunian, mengakomodasi nilai-nilai dikehidupan masyarakat mengenai ekonomi ,budaya, dan cara hidup setempat, dan tampilan, makna dan fungsi sangat dipengaruhi oleh sistem kepercayaan, struktur sosial, dan pola perilaku masyarakat.

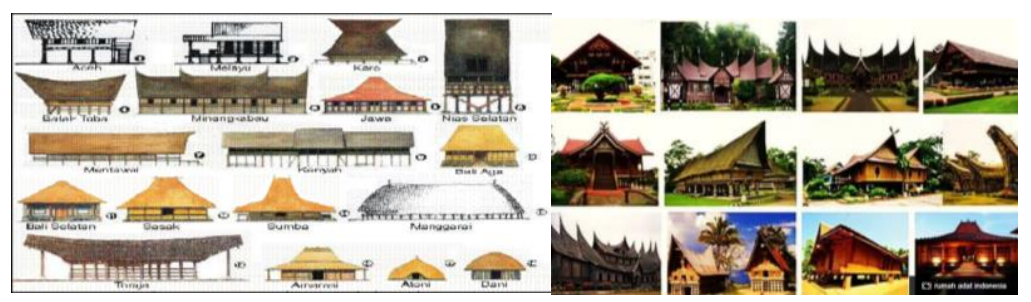

Gambar 1. Arsitektur Tradisional dan Arsitektur Vernacular di Indonesia Sumber: Diadaptasi dari [13], [14]

Secara umum terdapat tujuh aspek yang mempengaruhi arsitektur vernakular yaitu iklim, budaya, lingkungan alam, ilmu pengetahuan dan teknologi, hukum adat, aspek religi/kepercayaan dan hubungan sosial masyarakat [9]. Dalam karya arsitektur, dapat disimpulkan bahwa Arsitektur tradisional merupakan bagian dari arsitektur vernakular, yang merupakan arsitektur rakyat dengan menggambarkan kondisi di mana bangunan itu dibangun sebagai identitas arsitektur setempat. Arsitektur vernakular dibangun oleh tukang yang terlatih berdasarkan pengalaman yang dimilikinya melalui teknik sederhana dan menggunakan material lokal, sehingga desain arsitektur di setiap daerah berbeda-beda.

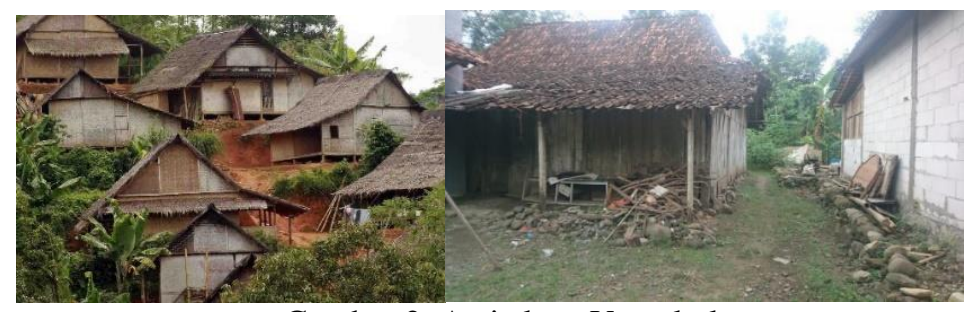

Gambar 2. Arsitektur Vernakular

Sumber: Diadaptasi dari [15], [16]

c. Arsitektur Modern Indonesia

1) Arsitektur Kolonial

Bangunan kolonial di Indonesia berkembang dalam dua style, yaitu gaya Eropa (klasik) dan akulturasi gaya arsitektur barat dan timur sebagai adaptasi arsitektur tropis. Perkembangan Gaya arsitektur Kolonial di Indonesia terbagi menjadi tiga yaitu; (a) Indische Empire Style 
(gaya Imperial) (Abad 18-19) adalah suatu gaya arsitektur yang berkembang pada pertengahan abad ke-18 sampai akhir abad ke-19 [10], [11], [12].

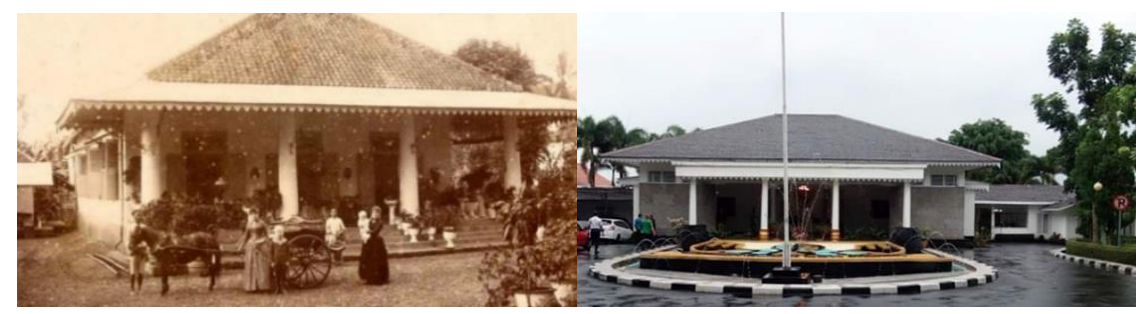

Gambar 3. Rumah Tinggal Indische dan Bangunan Bergaya Indische Sumber: Diadaptasi dari [17], [18]
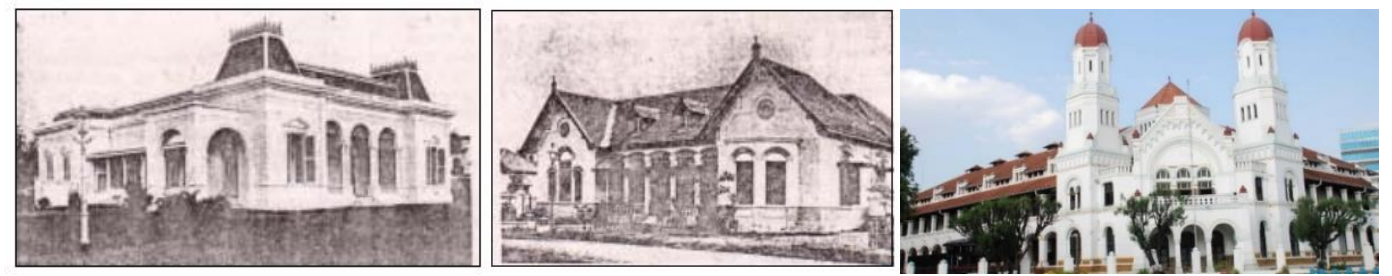

Gambar 4. Rumah Tingga bergaya Arsitektur Transisi dan Lawang Sewu Sumber: Diadaptasi dari [19], [20]

Ciri-ciri arsitektur Indische Empire Style antara lain; denahnya berbentuk simetris, di tengah ruangan terdapat "central room" yang terdiri dari kamar tidur utama dan beberapa kamar tidur lainnya. Central room langsung berhubungan dengan teras bagian depan dan teras bagian belakang (voor galerij dan achter galerij), teras memiliki luasan yang besar dan terdapat barisan kolom Yunani (Doric, Ionic, Corinthian) pada bagian ujungnya. Dapur, kamar mandi/WC, gudang dan daerah servis terpisah dari bangunan utama. Dan di bagian belakang terdapat paviliun di samping bangunan utama yang difungsikan sebagai kamar tidur tamu, konstruksi atap perisai dengan penutup atap genting, konstruksi utamanya bermaterial batu bata pada kolom dan dinding, pemakaian kayu khususnya pada konstruksi kuda-kuda, kusen maupun pintunya, belum banyak pemakaian material kaca. (b) Arsitektur transisi (1890-1915) berlangsung pada akhir abad 19 sampai awal abad 20 antara tahun 1890 sampai 1915. Pada masa ini terjadi modernisasi dengan penemuan baru yang berdampak pada perubahan bentuk dan gaya dalam bidang arsitektur [19]. Ciri-ciri arsitektur transisi antara lain; denah simetri, teras mengelilingi denah, ada keinginan menghilangkan kolom Yunani pada fasad, kolom-kolom sudah memakai kayu dan beton, serta dinding pemikul, muncul gevel-gevel pada arsitektur Belanda yang berada di tepi sungai, memberikan kesan romantis pada tampak dan membuat menara (tower) pada pintu masuk utama. Bentuk atap pelana dan perisai, menggunakan penutup genteng, dengan kemiringan besar antara $45^{\circ}-60^{\circ}$, pemakaian ventilasi pada atap (dormer), bahan bangunan utama bata dan kayu dan pemakaian kaca masih sangat terbatas [19], [21].

(c) Arsitektur Kolonial Modern (1915-1940) berkembang sesudah tahun 1900, yang merupakan sebuah protes gaya Empire Style [21]. Arsitektur modern memiliki ciri-ciri denah lebih bervariasi, di mana; menghindari bentuk simetri, teras tidak mengelilingi bangunan, menggunakan elemen penahan sinar matahari, menghilangkan kesan tampak arsitektur gaya "Indische Empire" (tampak tidak simetri lagi), tampak bangunan lebih mencerminkan "Form Follow Function" atau "Clean Design", bentuk atap didominasi atap pelana atau perisai, bahan penutup genteng atau sirap, sebagian bangunan dengan konstruksi beton, memakai atap datar dari bahan beton, pemakaian gevel horizontal, mulai menggunakan besi cor, memakai bahan kaca dalam jumlah yang besar, dominan meggunakan warna putih, dinding hanya berfungsi sebagai penutup dan penggunaan kaca (terutama pada jendela) yang cukup lebar. 


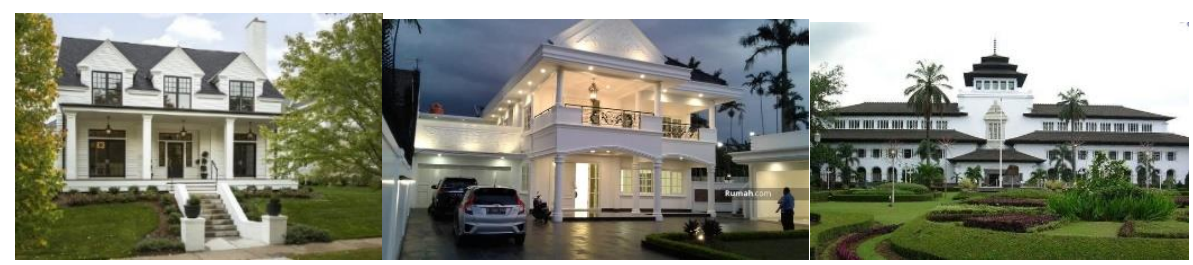

Gambar 5. Rumah Tinggal dan Gedung Sate

Sumber: Diadaptasi dari [22], [23], [24]

2) Arsitektur internasionalisme dan regionalisme
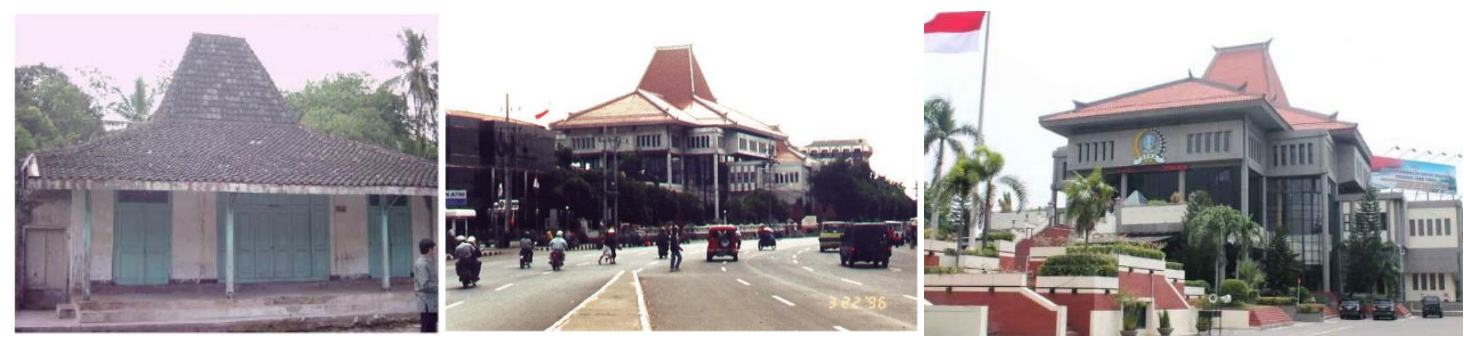

Gambar 6. Contoh Concrete Regionalism pada Gedung DPRD Jawa Timur Sumber: Diadaptasi dari [25]

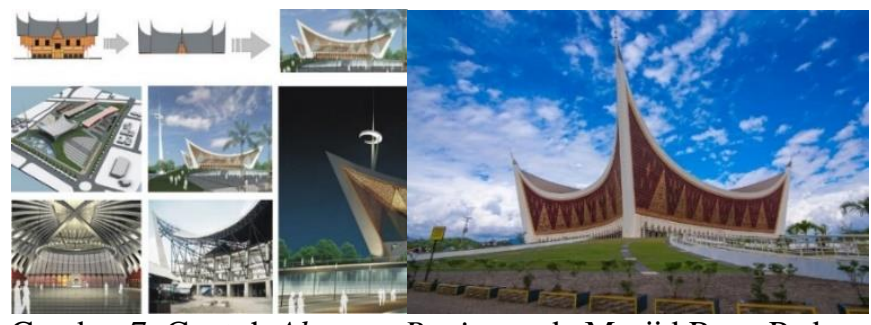

Gambar 7. Contoh Abstract Region pada Masjid Raya Padang

Sumber: Diadaptasi dari [26], [27]

Arsitektur internasionalisme dan regionalisme, merupakan arsitektur bergaya modern dan berkembang pasca kemerdekaan, di mana dipengaruhi oleh perkembangan teknologi yang semakin pesat serta pengaruh budaya asing yang masuk ke Indonesia. Untuk bangunan modern didominasi oleh bangunan tinggi dengan material dan sistem konstruksi berteknologi (pabrikasi). Pengaruh arsitektur modern mengaburkan jati diri Indonesia, sehingga bangkit arsitektur regionalisme yang ingin menampilkan kontektualitas kedaerahan. Regionalisme berkembang sekitar tahun 1960, dengan ciri-ciri; menggunakan bahan bangunan lokal dengan teknologi modern, tanggap dalam mengatasi kondisi iklim setempat, mengacu pada tradisi, warisan sejarah serta makna ruang dan tempat, mencari makna dan substansi kultural, bukan gaya/style sebagai produk akhir, menyatunya arsitektur tradisional dengan arsitektur modern. Di dalam [28], [29], [30] membagi regionalisme menjadi dua bagian yaitu: (a) Concrete Regionalism, pendekatan ekspresi daerah dengan melambangkan kehebatan, bagian-bagian atau seluruh bangunan di daerahnya. Bangunan akan lebih dikenal, karena memperlihatkan nilai-nilai yang melekat pada bentuk aslinya, sehingga akan lebih nyaman dan selaras dengan lingkungannya. Regionalisme merupakan cara berfikir dalam arsitektur yang bukan hanya memikirkan fisiknya secara tunggal namun tetap menjadi bagian dari jalur tertentu di lingkungannya, sehingga dapat mempertahankan citra setempat [28]. (b) Abstract Region, yaitu menekankan pada penggabungan unsur-unsur dan kualitas yang bersifat abstrak pada bangunan, yang dikaitkan langsung pada komposisi tata masa bangunan, fungsi dan pengalaman meruang, skala dan proporsi, komposisi solid-void, pencahayaan, pengalaman meruang, serta struktur dan teknologi yang diolah Kembali menjadi bentukan yang baru. Kritik yang dimaksud adalah sebuah rujukan yang mengadaptasi nilai-nilai universal modern, sekaligus mempertimbangkan konteks geografis sebuah bangunan. Abstrak region tidak merujuk pada kearifan lokal, namun, menanggapi kondisi iklim, pencahayaan, 
topografi dan tektonika lokal yang dapat dimengerti sebagai kondisi eksisting, geografis dan riwayat pembangunan [28]. Hal ini menjadi ukuran dalam menterjemahkan arsitektur di masa kini, sehingga memiliki wujud modern dan mengekspresikan akar budaya lokal.

3) Arsitektur Tropis

Arsitektur tropis adalah arsitektur yang dirancang untuk memodifikasi iklim tropis luar yang tidak nyaman menjadikan iklim di dalam bangunan yang nyaman. Penerapan arsitektur tropis Indonesia ditentukan melalui bentuk-bentuk yang menanggapi kondisi wilayah tropis serta pemanfaatan material yang tidak membahayakan lingkungan [31]. Arsitektur tropis dapat diartikan sebagai rancangan spesifik suatu karya arsitektur yang mengarah pada pemecahan problematik iklim tropis, di mana Arsitektur tropis diharapkan mampu menjawab seluruh persoalan iklim tersebut dengan bentuk rancangan yang hampir tanpa batas. Pertimbangan dalam penerapan arsitektur tropis adalah; penanaman pohon peneduh di sekitar bangunan sebagai upaya menghalangi radiasi matahari langsung dan mengurangi transfer panas berlebih ke dalam bangunan, pendinginan malam hari (night passive cooling), dengan menggunakan material yang bermasa time-lag besar (beton dan bata), untuk memperlambat proses konveksi panas, meminimalkan perolehan panas (heat gain) dari radiasi matahari pada bangunan, dengan cara menghalangi radiasi matahari langsung pada dinding-dinding transparan, mengurangi transmisi panas dari dindingdinding masif yang terkena radiasi matahari langsung, dengan membuat dinding lapis (berongga) yang diberi ventilasi pada rongganya (secondary skin), menempatkan ruangruang servis (tangga, toilet, pantry, gudang, dsb.) pada sisi-sisi jatuhnya radiasi matahari langsung (sisi timur dan barat), memberi ventilasi pada ruang antara atap dan langit-langit (pada bangunan rendah) agar tidak terjadi akumulasi panas pada ruang tersebut, serta memaksimalkan pelepasan panas dalam bangunan, dengan pemecahan rancangan arsitektur yang memungkinkan terjadinya aliran udara silang secara maksimum di dalam bangunan [30], [32], [33].

Disimpulkan bahwa arsitektur tropis adalah sebuah pemikiran dan budaya yang tumbuh dan berkembang di wilayah iklim tropis, di mana dapat berkembang seiring dengan kemajuan waktu, pemikiran, dan teknologi. Adapun prinsip dasar yang harus diperhatikan pada arsitektur tropis lembab adalah: pemanfaatan angin untuk ventilasi, perlindungan terhadap radiasi matahari dengan memperhitungkan garis lintasan matahari, mencegah akumulasi kelembaban pada ruangan dan perlindungan terhadap air hujan yang masuk ke dalam ruangan [31], [34]. Ciri-ciri bangunan yang berkembang di iklim tropis Indonesia, adalah (a) pada bangunan nusantara umumnya dijumpai bangunan yang memiliki atap dengan kemiringan yang besar untuk mengatasi radiasi matahari, dinding bercelah untuk memaksimalkan penghawaan udara, lantai panggung berpori untuk mengurangi kelembaban, dan roof overhang (teritisan atap) untuk melindungi bukaan dan dinding dari panas matahari berlebih dan hujan. (b) Pada bangunan modern dan bangunan bertingkat tinggi di Indonesia, penerapan tropis terlihat pada [31], [34]; penerapan penghawaaan dan pencahayaan alami diterapkan pada lantai 1-3, menempatkan teras dan balkon pada bagian badan bangunan, sebagai penghubung antar ruang luar dan ruang dalam, sekaligus menjadi dinding kanopi, menggunakan kanopi yang lebar pada teras dan lobby, penggunaan sirip balkon yang overstake untuk melindungi pancaran matahari langsung sekaligus membantu pemeliharaan dinding kaca, penerapan selubung vertikal sebagai secondary skin, kemiringan atap berkurang dan cenderung menggunakan atap datar dan didominasi material beton dan kaca. 


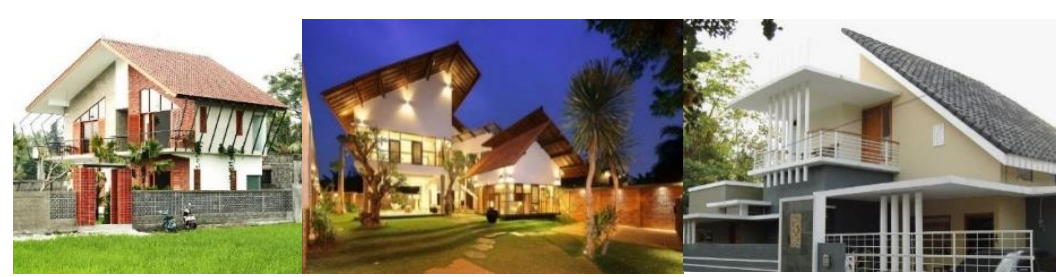

Gambar 8. Rumah Tropis

Sumber: Diadaptasi dari [35], [36], [37]

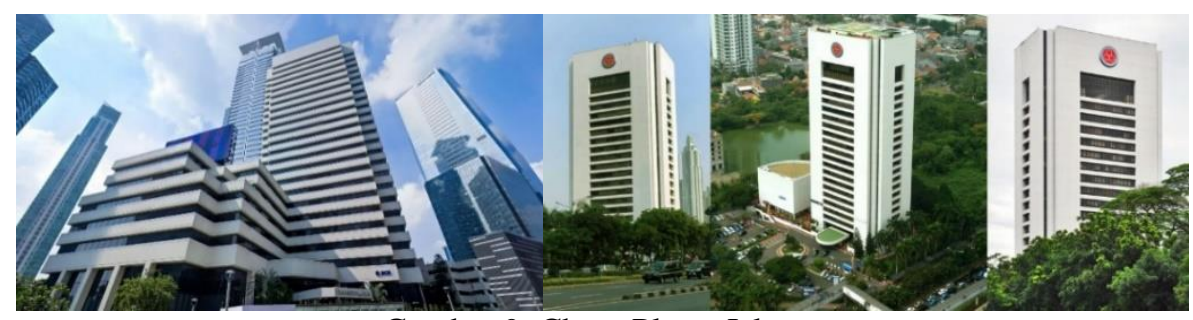

Gambar 9. Chase Plaza, Jakarta

Sumber: Diadaptasi dari [38], [39]

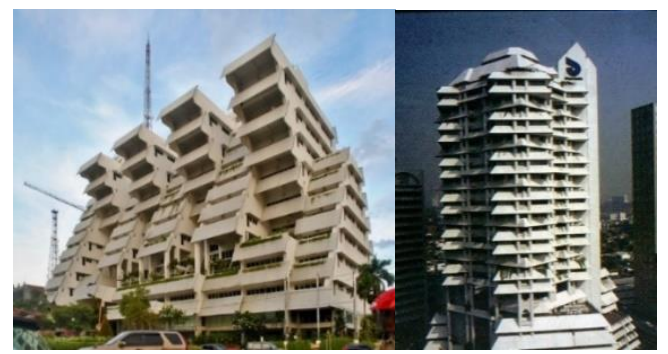

Gambar 10. Intiland Tower, Surabaya dan Wisma Darmala Sakti, Jakarta Sumber: Diadaptasi dari [40], [41]

\subsection{Analisis Pergeseran Desain Bangunan Pada Setiap Masa Perkembangan Arsitektur Indonesia}

Dari uraian beberapa hasil penelitian terdahulu dan tulisan para ahli terkait corak arsitektur dalam masa perkembangan arsitektur di Indonesia, maka analisis pergeseran desainnya akan diuraikan pada Tabel 1.

Tabel 1. Desain Bangunan pada Perkembangan Arsitektur Indonesia

\begin{tabular}{|c|c|c|c|c|}
\hline No. & Gaya Arsitektur & Ciri-ciri Fisik & Bentuk & Pergeseran \\
\hline 1 & $\begin{array}{l}\text { Arsitektur } \\
\text { Tradisional }\end{array}$ & $\begin{array}{l}\text { Bermaterial kayu, sistem } \\
\text { konstruksi pasak, atap besar, } \\
\text { dinding dan lantai kayu } \\
\text { berpori, lantai datar } \\
\text { langsung di atas tanah }\end{array}$ & $\begin{array}{l}\text { Bentuk denah geometri } \\
\text { dasar, hanya berlantai } \\
\text { satu }\end{array}$ & $\begin{array}{l}\text { Murni sesuai dengan } \\
\text { tradisi setempat }\end{array}$ \\
\hline 2 & $\begin{array}{l}\text { Arsitektur } \\
\text { Vernakular }\end{array}$ & $\begin{array}{l}\text { Berpedoman pada arsitektur } \\
\text { tradisional, mencerminkan } \\
\text { tempat, material lokal } \\
\text { disesuaikan waktu, tempat } \\
\text { dan kebutuhan. }\end{array}$ & $\begin{array}{l}\text { Ruang dan bentuk } \\
\text { memperhatikan } \\
\text { kebutuhan penghuni }\end{array}$ & $\begin{array}{ll}\text { - } & \text { Penambahan } \\
\text { ruang sesuai } \\
\text { kebutuhan } \\
\text { - } \quad \text { Material lokal } \\
\text { sesuai masa dan } \\
\text { kebutuhan }\end{array}$ \\
\hline \multirow[t]{2}{*}{3} & $\begin{array}{l}\text { Arsitektur } \\
\text { Modern } \\
\text { Indonesia: }\end{array}$ & & & \\
\hline & $\begin{array}{l}\text { Arsitektur } \\
\text { Kolonial }\end{array}$ & $\begin{array}{l}\text { Indische Empire Style: } \\
\text { Teras sangat luas, barisan } \\
\text { kolom bergaya Yunani, } \\
\text { konstruksi utama batu bata, } \\
\text { material kayu pada pintu, }\end{array}$ & $\begin{array}{l}\text { Indische Empire Style: } \\
\text { Denah simetris penuh, } \\
\text { atap perisai, material } \\
\text { penutup genteng } \\
\text { Arsitektur Transisi: } \\
\text { Denah simetri penuh, }\end{array}$ & 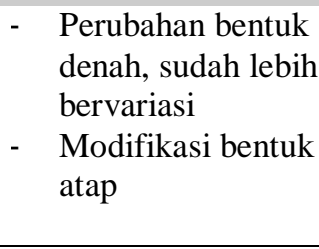 \\
\hline
\end{tabular}




\begin{tabular}{|c|c|c|c|c|}
\hline No. & Gaya Arsitektur & Ciri-ciri Fisik & Bentuk & Pergeseran \\
\hline & & $\begin{array}{l}\text { kusen dan konstruksi atap, } \\
\text { sedikit pemakaian kaca. } \\
\text { Arsitektur Transisi: Teras } \\
\text { mengelilingi denah, kolom } \\
\text { memakai kayu dan beton, } \\
\text { dinding pemikul, material } \\
\text { utama bata dan kayu, } \\
\text { pemakaian kaca pada } \\
\text { jendela masih sangat } \\
\text { terbatas. } \\
\text { Arsitektur Kolonial } \\
\text { Modern: Teras tidak lagi } \\
\text { berkeliling, penutup atap } \\
\text { genting atau sirap, sebagian } \\
\text { memakai konstruksi beton, } \\
\text { atap datar beton, Mulai } \\
\text { menggunakan besi cor, } \\
\text { sudah mulai memakai kaca } \\
\text { dalam jumlah besar, dinding } \\
\text { tidak lagi sebagai struktur. }\end{array}$ & $\begin{array}{l}\text { mengurangi kolom } \\
\text { Yunani, terdapat Gevel- } \\
\text { gevel, tampak romantik, } \\
\text { terdapat menara pada } \\
\text { pintu utama, atap pelana } \\
\text { dan perisai, penutup atap } \\
\text { genting, kemiringan atap } \\
\text { antara } 45^{\circ}-60^{\circ} \text {. Ventilasi } \\
\text { pada atap (dormer), } \\
\text { Arsitektur Kolonial } \\
\text { Modern: Bentuk denah } \\
\text { dan tampak tidak } \\
\text { simetris, Form Follow } \\
\text { Function atau Clean } \\
\text { Design, atap didominasi } \\
\text { pelana atau perisai, gevel } \\
\text { horizontal, dominan } \\
\text { berwarna putih }\end{array}$ & $\begin{array}{ll}\text { - } & \text { Material } \\
\text { cenderung batu } \\
\text { bata dan beton } \\
\text { - } & \text { Mulai } \\
\text { menggunakan besi } \\
\text { - } & \text { Bentuk fasad } \\
\text { dipengaruhi style } \\
\text { kolonial Belanda } \\
\text { - }\end{array}$ \\
\hline & $\begin{array}{l}\text { Arsitektur } \\
\text { Internasional dan } \\
\text { Regionalisme }\end{array}$ & $\begin{array}{l}\text { Material lokal berteknologi } \\
\text { modern, respon terhadap } \\
\text { iklim, pertimbangan tradisi, } \\
\text { sejarah serta makna ruang } \\
\text { dan tempat, menyatukan } \\
\text { arsitektur tradisional dengan } \\
\text { arsitektur modern. }\end{array}$ & $\begin{array}{l}\text { Penekanan pada makna } \\
\text { cultural bukan } \\
\text { gaya/style, Concrete } \\
\text { Regionalism, Abstract } \\
\text { Region }\end{array}$ & $\begin{array}{l}\text { - Penggunaan } \\
\text { material lokal dan } \\
\text { sistem teknologi } \\
\text { - Membangkitkan } \\
\text { nilai kedaerahan } \\
\text { (budaya, iklim dan } \\
\text { teknologi) }\end{array}$ \\
\hline & Arsitektu Tropis & $\begin{array}{l}\text { Pemanfaatan angin, } \\
\text { perlindungan terhadap } \\
\text { radiasi matahari, mencegah } \\
\text { kelembaban, perlindungan } \\
\text { terhadap air hujan, } \\
\text { pemanfaatan vegetasi } \\
\text { sebagai peneduh bangunan }\end{array}$ & $\begin{array}{l}\text { Hunian: kemiringan } \\
\text { Atap besar, dinding } \\
\text { bercelah, lantai } \\
\text { dinaikkan, overhang. } \\
\text { Bangunan lebih dari } 1 \\
\text { lantai: sistem alami } \\
\text { pada tingkat bawah } \\
\text { (lantai 1-3), teras dan } \\
\text { balkon di badan } \\
\text { bangunan, kanopi lebar } \\
\text { di lobby, sirip balkon, } \\
\text { overstake, secondary } \\
\text { skin, dominasi beton dan } \\
\text { kaca }\end{array}$ & $\begin{array}{l}\text { - Sistem teknologi } \\
\text { modern } \\
\text { - Pengembangan } \\
\text { lantai vertikal } \\
\text { - Prinsip kanopi dan } \\
\text { overstake } \\
\text { dikembangkan } \\
\text { secara vertikan } \\
\text { - Didominasi } \\
\text { material beton dan } \\
\text { kaca }\end{array}$ \\
\hline
\end{tabular}

\section{KESIMPULAN}

Dalam desain arsitektur dalam masa perkembangan arsitektur di Indonesia mengalami perkembangan dalam fasad dan pengaruhnya terhadap lingkungan. Adapun pergeseran desain bangunan dalam masa perkembangan arsitektur di Indonesia terlihat pada:

a. Penggunaan material dari lokal ke modern, dari penggunaan kayu ke penggunaan beton dan kaca.

b. Prinsip penerapan material dari penggunaan pasak secara manual mengalami pergeseran dengan sistem teknologi.

c. Perubahan penggunaan elemen lantai: lantai tanah, lantai panggung bermaterial kayu, lantai bertingkat rendah, lantai bertingkat tinggi.

d. Pergeseran atap: atap lebar berkemiringan tinggi dengan material alami, atap berkemiringan sedang dengan material pabrikasi, atap datar dengan material beton.

e. Style bangunan: penyesuaian lingkungan dan budaya, penyesuaian dengan kebutuhan penghuni, pengaruh budaya asing, pengaruh perkembangan teknologi, pengaruh perubahan iklim. 


\section{UCAPAN TERIMA KASIH}

Ucapan terimakasih kepada tim Program Studi Arsitektur Universitas Muhammadiyah Aceh dan Fakultas Teknik Universitas Muhammadiyah Aceh.

\section{DAFTAR PUSTAKA}

[1] F. Moore and M.-H. architecture and urban planninig series, Environmental control systems: Heating, cooling, lighting. McGraw-Hill New York, 1993.

[2] M. Hidayatun I, J. Prijotomo, and M. Rachmawati, "Arsitektur di Indonesia Dalam Perkembangan Jaman, Sebuah Gagasan untuk Jati diri Arsitektur di Indonesia.," Seminar Nasional Arsitektur Merah-Putih, no. Ruang dan tempat dalam latar Indonesia. Petra Christian University, 2014.

[3] G. Suharjanto, "Membandingkan Istilah Arsitektur Tradisional Versus Arsitektur Vernakular: Studi Kasus Bangunan Minangkabau dan Bangunan Bali," ComTech Comput. Math. Eng. Appl., vol. 2, no. 2, p. 592, 2011, doi: 10.21512/comtech.v2i2.2808.

[4] Y. H. Prasetyo and S. Astuti, "Ekspresi Bentuk Klimatik Tropis Arsitektur Tradisional Nusantara Dalam Regionalisme," J. Permukim., vol. 12, no. 2, pp. 80-93, 2017.

[5] L. Lefaivre and A. Tzonis, Architecture of Regionalism in the Age of Globalization. Academy Press, 2020.

[6] O. Hendrik and A. Rogi, “Arsitektur Vernakular : Patutkah Didefinisikan ?,” vol. 3, no. 2, pp. 3239, 2011.

[7] I. Mentayani and P. R. Muthia, "Menggali Makna Arsitektur Vernakular: Ranah, Unsur, dan AspekAspek Vernakularitas," LANTING J. Archit., vol. 1, no. 2, pp. I109-I116, 2017, doi: 10.32315/ti.6.i109.

[8] G. Tjahjono, "Indonesian Heritage: Architecture," Grolier Int., 1998.

[9] E. Septianto, A. R. Hakim, R. septian Sudrajat, S. Nurzaman, and Y. Suparman, "Kajian Arsitektur Vernakular Pada Bangunan Di Kampung Mahmud," J. Reka Karsa Arsit. Itenas, vol. 2, no. 4, pp. $1-10,2014$.

[10] H. Purnomo, J. O. Waani, and C. E. V Wuisang, "Gaya \& Karakter Visual Arsitektur Kolonial Belanda Di Kawasan Benteng Oranje Ternate," Media Matrasain, vol. 14, no. 1, pp. 23-33, 2017.

[11] L. T. Tarore and I. R. B. Kaunang, "Karakteristik Tipologi Arsitektur Kolonial Belanda Pada Rumah Tinggal Di Kawasan Tikala," Jurnal Arsitektur DASENG, vol. 5, no. 2. Sam Ratulangi University, pp. 1-9, 2016.

[12] Handinoto, "Perkembangan Kota dan Arsitektur Kolonial Belanda di Surabaya 1870-1940 [The Development of Dutch Colonial Urban and Architecture in Surabaya 1870-1940].” Diterbitkan atas kerjasama Lembaga Penelitian dan Pengabdian kepada Masyarakat, Universitas Kristen PETRA Surabaya dan Penerbit ANDI Yogyakarta, Yogyakarta, 1996, [Online]. Available: http://books.google.com/books?id=ouDVAAAAMAAJ.

[13] “[PDF] ARSITEKTUR VERNAKULAR - Free Download PDF," 2017. https://edoc.tips/download/arsitektur-vernakular_pdf\#modals (accessed Aug. 01, 2021).

[14] Rizki, "Nama-nama Rumah Adat di Indonesia Lengkap Gambar dan Penjelasan," 2021. https://pastiguna.com/rumah-adat/ (accessed Aug. 01, 2021).

[15] A. Rusdiyanto, "Arsitektur Vernakuler Baduy-Provinsi Banten." https://id.pinterest.com/pin/458030224581094475/ (accessed Aug. 01, 2021).

[16] Fathoniarief, "Semua Tentang Arsitektur Tanpa Arsitek," 2021. https://fathoniarief.com/semuatentang-arsitektur-tanpa-arsitek/ (accessed Aug. 01, 2021).

[17] H. T. Hanggoro, "Pamer Kekayaan di Rumah Indische Woonhuis - Historia," 2019. https://historia.id/urban/articles/pamer-kekayaan-di-rumah-indische-woonhuis-vXINY/page/1 (accessed Aug. 01, 2021).

[18] Metro Sukabumi, "Bangunan Bergaya Indische Empire Style Abad Ke-18 - Metropolitan.id," 2019. https://www.metropolitan.id/2019/04/bangunan-bergaya-indische-empire-style-abad-ke-18/ (accessed Aug. 01, 2021).

[19] Handinoto Handinoto and Samuel Hartono, “'ARSITEKTUR TRANSISI' DI NUSANTARA DARI AKHIR ABAD 19 KE AWAL ABAD 20 (Studi Kasus Komplek Bangunan Militer di Jawa pada Peralihan Abad 19 ke 20)," Dimens. (Jurnal Tek. Arsitektur), vol. 34, no. 2, pp. 81-92, Jan. 2006, [Online]. Available: http://puslit2.petra.ac.id/ejournal/index.php/ars/article/view/16540.

[20] BPCB Jateng, "Gaya Arsitektur Transisi pada Gedung Lawang Sewu - Balai Pelestarian Cagar Budaya Jawa Tengah,” 2020. http://kebudayaan.kemdikbud.go.id/bpcbjateng/gaya-arsitektur- 
transisi-pada-gedung-lawang-sewu/ (accessed Aug. 01, 2021).

[21] N. Tamimi, I. S. Fatimah, and A. A. Hadi, "Tipologi Arsitektur Kolonial di Indonesia," J. Arsitektur, Bangunan dan Lingkung., vol. 10, p. 8, Oct. 2020, [Online]. Available: https://publikasi.mercubuana.ac.id/index.php/virtuvian/article/view/7885.

[22] K. Dekoruma, "Bergaya Kolonial dengan 6 Inspirasi Rumah Belanda Modern!," 2019. https://www.dekoruma.com/artikel/78547/inspirasi-rumah-belanda-modern (accessed Aug. 01, 2021).

[23] "Kemang, Rumah Baru Design Kolonial Modern," 2021. https://www.rumah.com/listingproperti/dijual-kemang-rumah-baru-design-kolonial-modern-oleh-nina-ika-dewandari-17802529 (accessed Aug. 01, 2021).

[24] Arsitur Studio, "Perkembangan Arsitektur Kolonial di Indonesia Beserta Contoh-contohnya," 2020. https://www.arsitur.com/2017/03/perkembangan-arsitektur-kolonial-di.html (accessed Aug. 01, 2021).

[25] Y. Santosa, "Regionalisme,” 2010. https://dokumen.tips/documents/regional-is-me.html (accessed Aug. 01, 2021).

[26] Nasbahry, "Masalah Regionalisme dalam Desain Arsitektur," 2011. https://visualheritageblog.blogspot.com/2011/04/5masalah-regionalisme-dalam-desain.html (accessed Aug. 01, 2021).

[27] A. Sathya, "Megahnya Masjid Raya Padang, Ikon Religi khas Minangkabau," 2019. https://www.pegipegi.com/travel/megahnya-masjid-raya-padang-ikon-religi-khas-minangkabau/ (accessed Aug. 01, 2021).

[28] B. B. Senasaputro, "Kajian Arsitektur Regionalisme; Sebagai Wacana Menuju Arsitektur Tanggap Lingkungan Berkelanjutan," Ultim. J. Komun. Vis., vol. 10, no. 2, pp. 73-84, 2018, doi: 10.31937/ultimart.v10i2.777.

[29] M. Sulthon, "REDESAIN MUSEUM PURBAKALA PATIAYAM KUDUS Dengan Pendekatan Arsitektur Regionalism Landasan Program Perencanaan Dan Perancangan Arsitektur.” Universitas Negeri Semarang, 2016.

[30] T. H. Karyono, "Mendefinisikan kembali Arsitektur tropis di Indonesia," Desain Arsit., vol. 1, no. April 2000, pp. 7-8, 2000.

[31] A. Dananjaya, A. F. Priyatmono, and S. Raidi, "Identifikasi Fasad Arsitektur Tropis Pada GedungGedung Perkantoran Jakarta (Studi Kasus Pada Koridor Dukuh Atas-Semanggi)," Sinektika: Jurnal Arsitektur, vol. 13, no. 2. Universitas Muhammadiyah Surakarta, pp. 125-135, 2015, doi: 10.23917/sinektika.v13i2.756.

[32] T. H. Karyono, “Arsitektur tropis bangunan hemat energi," J. Ilm. Arsit. UPH, vol. 1, 2004.

[33] T. H. Karyono, "Kenyamanan Termal dalam Arsitektur Tropis," Researchgate, no. July, p. 9, 2016.

[34] G. Hardiman, "Pertimbangan iklim tropis lembab dalam konsep arsitektur bangunan modern," $J$. Arsit. Univ. Bandar Lampung, vol. 2, no. 2, pp. 77-82, 2012, [Online]. Available: http://jurnal.ubl.ac.id/index.php/ja/article/view/307.

[35] Archifynow, "Rumah Kubu Tropis - Menjadikan Arsitektur sebagai Branding," 2017. https://www.archify.com/id/archifynow/rumah-kubu-tropis-menjadikan-arsitektur-sebagaibranding (accessed Aug. 01, 2021).

[36] A. Kristy, "10 Desain Rumah Tropis Modern \& Minimalis Terbaik," 2019. https://www.tokopedia.com/blog/desain-rumah-tropis-modern/ (accessed Aug. 01, 2021).

[37] "4 Ciri Rumah Berkonsep Arsitektur Tropis," 2018. https://www.aca.co.id/Info-Asuransi-Detail/4Ciri-Rumah-Ber-konsep-Arsitektur-Tropis (accessed Aug. 01, 2021).

[38] "Chase Plaza - Miyamoto International." https://miyamotointernational.com/chase-plaza/ (accessed Aug. 01, 2021).

[39] PT. Perentjana Djaja, "Wisma Indocement Building - PT. Perentjana Djaja," 2020. https://www.perentjanadjaja.id/v2/wisma-indocement-building/ (accessed Aug. 01, 2021).

[40] DBG, "Intiland Tower Surabaya - Setiap Gedung Punya Cerita," 2018. https://setiapgedung.web.id/2018/12/wisma-intiland-surabaya.html (accessed Aug. 01, 2021).

[41] "Wisma Dharmala Sakti - The Skyscraper Center." https://www.skyscrapercenter.com/jakarta/ wisma- dharmala-sakti/5070 (accessed Aug. 01, 2021). 